\title{
Genetic Variability Studies for Yield and Quality Traits in Chickpea (Cicer arietinum L.)
}

\author{
T. Anusha ${ }^{1 *}$, A. Trivikrama Reddy ${ }^{1}$, V. Jayalakshmi ${ }^{2}$ and S. Khayum Ahammed ${ }^{2}$ \\ ${ }^{1}$ Department of Genetics and Plant Breeding, Agricultural College, Mahanandi-518502, India \\ ${ }^{2}$ Regional Agricultural Research Station, Nandyal-518501, India \\ *Corresponding author
}

\section{A B S T R A C T}

Ke y w o r d s
Chickpea, Genetic
variability,
Phenotypic
coefficient of
variation,
Genotypic
coefficient of
variation,
Heritability,
Genetic advance as
per cent of mean
Article Info
Accepted:
20 August 2020
Available Online:
10 September 2020

\section{Introduction}

Chickpea (Cicer arietinum L.) is highly selfpollinated diploid annual leguminous plant. It is the third most important pulse crop in the world after faba bean and field pea (Singh et al., 2018). India is the world's largest producer of chickpea with annual production of 10.13 million tonnes from an area of 9.44 million ha with productivity of $1073 \mathrm{~kg}$ ha-1 (Directorate of Economics and Statistics,
The present investigation was carried out with 25 chickpea genotypes to study the genetic variability parameters for yield and quality traits of chickpea and observed highly significant differences among the genotypes for all the eleven traits studied viz., plant height, number of branches plant ${ }^{-}$ ${ }^{1}$, days to $50 \%$ flowering, days to maturity, number of pods plant ${ }^{-1}, 100$ seed weight, harvest index, protein content, iron content, zinc content and seed yield plant ${ }^{-1}$. Genetic variability parameters showed moderate to high estimates of phenotypic coefficient of variation and genotypic coefficient of variation, with high heritability in broad sense coupled with high genetic advance as per cent of mean for the traits viz., plant height, number of pods plant $^{-1}, 100$ seed weight, seed yield plant ${ }^{-1}$ and iron content and thus, indicating that these characters exhibited wide range of variability. Heritability in these characters was due to additive gene effects and selection may be effective. This will help the breeders for direct selection of plants on the basis of phenotypic expression.
2019). Other important countries growing chickpea are Pakistan, Mexico, Turkey, Canada, Iran, Australia, Tanzania, Ethiopia, Spain and Burma. In Andhra Pradesh, chickpea is grown in an area of 4.78 lakh ha producing 2.43 lakh tonnes with productivity $506 \mathrm{~kg} / \mathrm{ha}$ (Directorate of Economics and Statistics, 2019).

Chickpea is highly nutritious crop and is a protein- rich supplement to cereal based diets. 
Chickpea seeds contain on an average $23 \%$ protein, $64 \%$ total carbohydrates $(47 \%$ starch, $6 \%$ soluble sugar), $5 \%$ fat, $6 \%$ crude fibre and $2 \%$ ash and also contain micro nutrients like phosphorus (340 mg/100 g), calcium (160 $\mathrm{mg} / 100 \mathrm{~g})$, magnesium $(140 \mathrm{mg} / 100 \mathrm{~g})$, iron $(5 \mathrm{mg} / 100 \mathrm{~g})$, zinc $(4.1 \mathrm{mg} / 100 \mathrm{~g})$ (Jukanti et al., 2012). Since, cereals combined with pulses are a major diet for billions of people around the world, chickpeas are being targeted in many countries so that malnutrition problem can be controlled to some extent.

Genetic improvement of any crop mainly depends on the magnitude of genetic variability present in the breeding material and to extent to which the yield and quality characters are heritable from generation to generation. The estimates of genotypic and phenotypic coefficient are necessary for understanding the influence of environment on different traits.

Heritability and genetic advance as per cent of mean is a reliable tool in the selection programme to get a clear picture of the scope of improvement of various characters through selection. The identification of chickpea genotypes rich with protein and micronutrients along with good yield help the breeders to identify donars for the future breeding programme. Keeping this in view, the present investigation was carried out with the following objective to estimate the extent of genetic variability for yield and quality traits in chickpea.

\section{Materials and Methods}

The present investigation was carried out with 25 genotypes comprising of 20 advanced desi breeding lines and 5 check lines at Regional Agricultural Research Station, Nandyal during rabi 2019-20 in a Randomized Block Design (RBD) with three replications and spacing of $30 \mathrm{~cm} \mathrm{x} 10 \mathrm{~cm}$ was adopted. Recommended agronomical and plant protection practices for chickpea crop were followed. Observations were recorded for 11 traits viz., plant height, number of branches plant $^{-1}$, number of pods plant ${ }^{-1}$, days to $50 \%$ flowering, days to maturity, 100 seed weight, harvest index, protein content, iron content, zinc content and seed yield plant ${ }^{-1}$ as per standard procedures.

For the estimation of protein content, mature seeds from each genotype in each replication were powdered and $0.2 \mathrm{~g}$ of powdered seed sample was digested with concentrated $\mathrm{H}_{2} \mathrm{SO}_{4}$ for determination of nitrogen content in per cent by using Micro - Kjeldhal digestion and distillation method as given by AOAC (1965).

The crude protein content in seeds was obtained by multiplying the determined nitrogen content with 6.25. A known quantity of $0.2 \mathrm{~g}$ powdered sample was digested with triacid mixture (nitric acid, sulfuric acid and perchloric acid @ 9:4:1) to determine the iron content and zinc content by using Atomic Absorption Spectrophotometer.

Analysis of variance was carried out for each character separately as per the method outlined by Panse and Sukhatme (1985). The genotypic coefficient of variation (GCV) and phenotypic coefficient of variation (PCV) were estimated as per the formula suggested by Burton (1952) while heritability in broad sense by Lush (1940) and genetic advance as per cent of mean by Johnson et al., (1955 a).

\section{Results and Discussion}

Analysis of variance revealed highly significant differences among the genotypes for all the 11 characters studied (Table 1) and shown a wide range of variability for the characters considered. 


\section{Range of variability}

The range of variability for plant height (29.0 $\mathrm{cm}$ to $47.5 \mathrm{~cm}$ ), number of branches plant ${ }^{-1}$ (11.2 to 18.4), days to $50 \%$ flowering ( 35.0 days to 53.3 days), days to maturity ( 81.0 days to 90.7 days), number of pods plant ${ }^{-1}$ (23.3 to 45.2$), 100$ seed weight (20.9 $\mathrm{g}$ to 36.0 $\mathrm{g})$, harvest index (50.5\% to $64.8 \%)$, protein content (18.1\% to $22.1 \%)$, iron content (6.5 $\mathrm{mg} / 100 \mathrm{~g}$ to $14.4 \mathrm{mg} / 100 \mathrm{~g}$ ), zinc content $(3.0$ $\mathrm{mg} / 100 \mathrm{~g}$ to $5.3 \mathrm{mg} / 100 \mathrm{~g}$ ) and seed yield plant $^{-1}$ (4.8 $\mathrm{g}$ to $12.0 \mathrm{~g}$ ) were observed in Table 2.

The variation among the chickpea genotypes in this study would provide ample opportunities for the genetic improvement of the crop through direct selection of genotypes or through hybridization using as parents possessing the desirable traits.

\section{Phenotypic and Genotypic coefficient of variation}

The estimates of phenotypic coefficient of variation (PCV) for all 11 characters were observed to be higher than the estimates of genotypic coefficient of variation (GCV) (Table 2), indicating the influence of environment on the expression of these characters which was also reported by Raju et al., (2017), Srivastava et al., (2017) and Mohammed et al., (2019). PCV and GCV values of more than $20 \%$ are considered to be high, values between $10-20 \%$ as medium and values less than $10 \%$ as low (Sivasubramanian and Menon, 1973).

In this study, iron content recorded high values of $\mathrm{PCV}$ and $\mathrm{GCV}$, indicating the presence of wide variability among the genotypes studied for this trait. On the other hand, days to $50 \%$ flowering, days to maturity, harvest index and protein content showed low levels of PCV and GCV, signifying limited scope for further genetic improvement through selection. The traits viz., plant height, number of branches plant ${ }^{-1}$, number of pods plant ${ }^{-1}, 100$ seed weight, zinc content showed moderate magnitude of PCV and GCV. Seed yield plant ${ }^{-1}$ exhibited high $\mathrm{PCV}$ and moderate GCV values.

These findings were in conformity with findings of Jayalakshmi et al., (2018) for iron content, Jayalakshmi and Trivikrama Reddy (2018) for protein content and zinc content, Raju et al., (2017) for days to $50 \%$ flowering, plant height and number of branches plant ${ }^{-}$ ${ }^{1}$ per plant. Similarly, Banik et al., (2018), Mohammed et al., (2019) and Mohan and Thiyagarajan (2019) for days to maturity, Kumar et al., (2018) for number of pods plant $^{-1}$

\section{Heritability in broad sense and genetic advance as per cent of mean}

High heritability in broad sense estimates was observed in Table 2 for characters viz., number of pods plant ${ }^{-1}(93.6 \%)$, iron content $(93.0 \%)$, days to $50 \%$ flowering $(91.7 \%), 100$ seed weight $(91.6 \%)$, plant height $(90.6 \%)$, days to maturity $(90.1 \%)$, and seed yield plant $^{-1}(73.0 \%)$ and thus indicated the presence of a considerable proportion of total genetic variance which includes fixable and non-fixable variances.

Moderate heritability estimates were recorded for harvest index $(57.3 \%)$, zinc content (57.1\%), number of branches plant ${ }^{-1}(49.0 \%)$ and protein content $(39.7 \%)$. Similar findings were also reported by Desai et al., (2015), Raju et al., (2017), Banik et al., (2018) and Singh et al., (2018) for plant height, days to $50 \%$ flowering, number of pods plant ${ }^{-1}, 100$ seed weight and seed yield plant ${ }^{-1}$; Mohan and Thiyagarajan (2019) for number of branches plant $^{-1}$ and protein content; Srivastava et al., (2017) for harvest index. 
Table.1 Analysis of variance for 11 characters in 25 genotypes of chickpea

\begin{tabular}{|c|c|c|c|c|}
\hline \multirow{3}{*}{ S.No } & \multirow[t]{3}{*}{ Characters } & \multicolumn{3}{|c|}{ Mean sum of squares } \\
\hline & & Replications & Treatments & Error \\
\hline & & $(\mathrm{df}: 2)$ & (df: 24) & (df: 48$)$ \\
\hline 1 & Plant height $(\mathrm{cm})$ & 10.1 & $58.1 * *$ & 1.9 \\
\hline 2 & Number of branches plant ${ }^{-1}$ & 8.6 & $8.7 * *$ & 2.2 \\
\hline 3 & Days to $50 \%$ flowering & 46.3 & $47.0 * *$ & 1.4 \\
\hline 4 & Days to maturity & 40.4 & $17.3 * *$ & 0.6 \\
\hline 5 & Number of pods plant ${ }^{-1}$ & 35.6 & $131.6 * *$ & 2.9 \\
\hline 6 & 100 seed weight $(\mathrm{g})$ & 1.1 & $40.8 * *$ & 1.2 \\
\hline 7 & Harvest index $(\%)$ & 0.3 & $37.3 * *$ & 7.4 \\
\hline 8 & Protein content $(\%)$ & 8.4 & $3.4 * *$ & 1.1 \\
\hline 9 & Fe content $(\mathrm{mg} / 100 \mathrm{~g})$ & 1.6 & $16.8 * *$ & 0.4 \\
\hline 10 & Zn content $(\mathrm{mg} / 100 \mathrm{~g})$ & 1.2 & $1.0 * *$ & 0.2 \\
\hline 11 & Seed yield plant ${ }^{-1}(\mathrm{~g})$ & 2.2 & $9.0 * *$ & 1.0 \\
\hline
\end{tabular}

** Significant at $1 \%$ level

Table.2 Estimates of genetic parameters for 11 characters in 25 chickpea genotypes

\begin{tabular}{|c|c|c|c|c|c|c|c|c|}
\hline \multirow[t]{2}{*}{ S.No. } & \multirow[b]{2}{*}{ Characters } & \multirow{2}{*}{$\begin{array}{l}\text { General } \\
\text { Mean }\end{array}$} & \multicolumn{2}{|c|}{ Range } & \multirow{2}{*}{$\begin{array}{c}\text { GCV } \\
(\%)\end{array}$} & \multirow{2}{*}{$\begin{array}{l}\text { PCV } \\
(\%)\end{array}$} & \multirow{2}{*}{$\begin{array}{c}\text { Heritability } \\
\text { (Broad sense) } \\
(\%)\end{array}$} & \multirow{2}{*}{$\begin{array}{l}\text { Genetic Advance } \\
\text { as per cent of mean }\end{array}$} \\
\hline & & & lowest & Highest & & & & \\
\hline 1 & Plant height $(\mathrm{cm})$ & 36.5 & 29.0 & 47.5 & 11.8 & 12.4 & 90.6 & 23.2 \\
\hline 2 & Number of branches plant ${ }^{-1}$ & 14.5 & 11.2 & 18.4 & 10.1 & 14.4 & 49.0 & 14.6 \\
\hline 3 & Days to $50 \%$ flowering & 46.3 & 35.0 & 53.3 & 8.4 & 8.8 & 91.7 & 16.6 \\
\hline 4 & Days to maturity & 84.6 & 81.0 & 90.7 & 2.8 & 2.9 & 90.1 & 5.5 \\
\hline 5 & Number of pods plant ${ }^{-1}$ & 33.9 & 23.2 & 45.2 & 19.3 & 20.0 & 93.6 & 38.5 \\
\hline 6 & 100 seed weight $(\mathrm{g})$ & 26.5 & 20.9 & 36.0 & 13.7 & 14.3 & 91.6 & 27.0 \\
\hline 7 & Harvest index (\%) & 58.0 & 50.5 & 64.8 & 5.4 & 7.2 & 57.3 & 8.5 \\
\hline 8 & Protein content $(\%)$ & 20.1 & 18.1 & 22.1 & 4.3 & 6.8 & 39.7 & 5.6 \\
\hline 9 & Fe content $(\mathrm{mg} / 100 \mathrm{~g})$ & 10.6 & 6.5 & 14.4 & 21.9 & 22.7 & 93.0 & 43.5 \\
\hline 10 & $\mathrm{Zn}$ content $(\mathrm{mg} / 100 \mathrm{~g})$ & 3.0 & 2.6 & 5.3 & 12.4 & 16.5 & 57.1 & 19.3 \\
\hline 11 & Seed yield plant ${ }^{-1}(\mathrm{~g})$ & 8.9 & 4.8 & 12.0 & 18.4 & 21.5 & 73.0 & 32.4 \\
\hline
\end{tabular}

GCV: Genotypic coefficient of variation; PCV: Phenotypic coefficient of variation 
Genetic advance as per cent of mean was high for iron content $(43.5 \%)$, number of pods plant $^{-1}(38.5 \%)$, seed yield plant ${ }^{-1}(32.4 \%)$, 100 seed weight $(27.0 \%)$ and plant height $(23.2 \%)$ thus showed that these characters were governed by additive genes and selection will be rewarding for improvement of these characters. Moderate genetic advance as per cent of mean was observed for zinc content $(19.3 \%)$, number of branches plant ${ }^{-1}$ (14.6\%) and days to 50\% flowering (16.6\%).

Low genetic advance as per cent of mean was observed for harvest index $(8.5 \%)$, protein content $(5.6 \%)$ and days to maturity $(5.5 \%)$ and thus indicated that these characters were governed by non-additive genes. Similar findings were also reported by Raju et al., (2017) and Singh et al., (2018) for 100 seed weight, plant height, days to $50 \%$ flowering; Jayalakshmi et al., (2018) for iron content; Desai et al., (2015) for protein content.

In the present investigation, plant height, number of pods plant ${ }^{-1}, 100$ seed weight, iron content and seed yield plant ${ }^{-1}$ showed high estimates of broad sense heritability coupled with high genetic advance as per cent of mean indicating that these characters could be prominently governed by additive gene action and selection of these traits may be more effective for desired genetic improvement.

It was supported by similar findings of Desai et al., (2015), Singh et al., (2018), Banik et al., (2018) for 100 seed weight, number of pods plant ${ }^{-1}$ and plant height; Jayalakshmi et al., (2018) for iron content.

In conclusion the present studies revealed that iron content showed high PCV and GCV whereas, plant height, number of branches plant $^{-1}$, number of pods plant ${ }^{-1}, 100$ seed weight, zinc content showed moderate magnitude of PCV and GCV. Seed yield plant $^{-1}$ exhibited high PCV and moderate
GCV values. The traits viz., plant height, number of pods plant ${ }^{-1}, 100$ seed weight, iron content and seed yield plant ${ }^{-1}$ showed high estimates of broad sense heritability coupled with high genetic advance as per cent of mean

The assessment of genetic parameters like phenotypic and genotypic coefficient of variation, heritability and genetic advance as per cent of mean indicated that selection must be done in the characters like plant height, number of pods plant ${ }^{-1}, 100$ seed weight, seed yield plant ${ }^{-1}$ and iron content for improving the yield and nutritional traits to generate genetic variability followed by selection in further generations to identify superior segregants for these characters.

\section{References}

AOAC. 1965. Official methods of analysis of the Association of Official Agricultural Chemists. 8th edition. Minnosta.

Banik, M., Deore, G.N., Mandal, A.K and Mhase, L.B. 2018. Genetic variability and heritability studies in chickpea (Cicer arietinum L.). Current Journal of Applied Sciences and Technology. 31(1): 1-6.

Burton, G.W. 1952. Quantitative inheritance in grasses. Proceedings of 6th Grassland Congress Journal. 1: 277281.

Desai, K., Tank, C.J., Gami, R.A., Patel, A.M and Patel, C. 2015. Character association analysis for yield, its components and nutritional quality in chickpea (Cicer arietinum L.). Research Journal of Agricultural Sciences. 6(6): 1280-1283.

Directorate of Economics and Statistics, 2019. Ministry of Agriculture Cooperation and Farmers Welfare (GOI). Agricultural statistics at a glance 2019. pp. 62-63.

Jayalakshmi, V and Trivikrama Reddy, A. 
2018. Genetic diversity assessment of Indian chickpea varieties for protein and micronutrient composition. Electronic Journal of Plant Breeding. 9(4): 13701377.

Jayalakshmi, V., Trivikrama Reddy, A and Nagamadhuri, K.V. 2018. Genetic diversity and variability for protein and micro nutrients in advance breeding lines and chickpea varieties grown in Andhra Pradesh. Legume Research. 1-5.

Johnson, H.W., Robinson, H.F and Comstock, R.E. 1955a. Estimation of genetic and environmental variability in soybean. Agronomy Journal. 47: 314-318.

Jukanti, A.K., Gaur, P.M., Gowda, C.L.L and Chibbar, R.N. 2012. Nutritional quality and health benefits of chickpea (Cicer arietinum. L): a review. British Journal of Nutrition. 108: S11S26.

Kumar, A., Nath, S., Kumar, A and Yadav, A.K. 2018. Study of variability, heritability and genetic advance for some quantitative traits in chickpea (Cicer arietinumL.). Journal of Pharmacognosy and Phytochemistry. 7(2): 487-489.

Lush, J.L. 1940. Intra-series correlation and regression of offspring in rams as a method of estimating heritability of characters. Proceedings of American Society of Animal Product. 33: 292-301. Mohammed, A., Tesso, B., Ojiewo, C., Ahmed, S. 2019. Assessment of genetic variability and heritability of agronomic traits in Ethiopian chickpea (Cicer arietinum L.) landraces. Black Sea Journal of Agriculture. 2(1): 10-15.

Mohan, S and Thiyagarajan,. 2019. Genetic variability, correlation and path coefficient analysis in chickpea (Cicer arietinum L.) for yield and its component traits. International Journal of Current Microbiology and Applied Sciences. 8(5): 1801-1808.

Panse, V.G and Sukhatme, P.V. 1985. Statistical methods for agricultural workers. ICAR Publication (2nd Ed.), New Delhi.

Raju, T., Sadhukhan, R., Satish, V. 2017. Genetic variability studies in chickpea (Cicer arietinum L.) for yield and yield related traits. Bulletin of Environment, Pharmacology and Life Sciences. 6(2): 177-183.

Singh, V., Singh, P., Kumar, A and Nath, S. 2018. Estimation of genetic variability parameters in chickpea (Cicer arietinum

L.) germplasm. Journal of Pharmacognosy and Phytochemistry. 7(2): 1204-1206.

Sivasubramanian, P and Menon, P.M. 1973. Inheritance of short stature in rice. Madras Agricultural Journal. 60: 11291133.

Srivastava, S., Roopa Lavanya, G and Lal, G.M. 2017. Genetic variability and character association for seed yield in chickpea (Cicer arietinum L.). Journal of Pharmacognosy and Phytochemistry. 6(4): 748-750.

\section{How to cite this article:}

Anusha, T., A. Trivikrama Reddy, V. Jayalakshmi and Khayum Ahammed, S. 2020. Genetic Variability Studies for Yield and Quality Traits in Chickpea (Cicer arietinum L.). Int.J.Curr.Microbiol.App.Sci. 9(09): 2995-3000. doi: https://doi.org/10.20546/ijcmas.2020.909.369 